\title{
甲状腺で機能性および非機能性結節が共存した患者の チログロブリンの性状
} 群馬大学医学部第二外科学教室 ${ }^{1)}$, 東京理科大学基礎工学部 ${ }^{2)}$

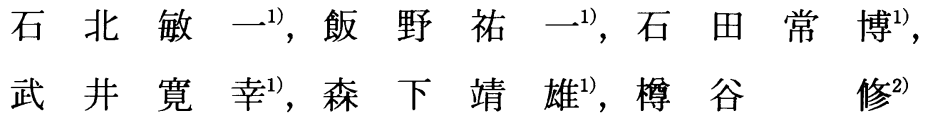

Characterization of Thyroglobulin in a Patient with Functioning and Non-Functioning Benign Thyroid Tumors

Toshikazu ISHIKITA ${ }^{1)}$, Yuichi IINO ${ }^{1)}$, Tunehiro ISHIDA ${ }^{1)}$, Hiroyuki TAKEI ${ }^{1)}$, Yasuo MORISHITA ${ }^{1)}$ and Osamu TARUTANI ${ }^{2)}$

1) The Second Department of Surgery, Gunma University School of Medicine, Maebashi 371, Japan

2) Division of Biological Chemistry, Science University of Tokyo, Noda 278, Japan

The chemical and immunological properties of thyroglobulin ( $\mathrm{Tg}$ ) in tissue obtained from a patient co-existed with two types of thyroid tumors, i.e., functioning and non-functioning, and were compared with the properties of $\mathrm{Tg}$ that was isolated from adjacent peripheral tissue.

In the present observations, the $\mathrm{Tg}$ content was markedly increased in the non-functioning thyroid tumor. On the other hand, the $\mathrm{Tg}$ content in the functioning tumor was at the normal level.

The iodine content of $\mathrm{Tg}$ was significantly lower in the non-functioning tumor than in peripheral tissues. Affinity with Lectins differed among Tg preparations, suggesting that the carbohydrate chain in the $\mathrm{Tg}$ was different in each nodule in a single individual.

Key words : Thyroglobulin, Functioning Thyroid Tumor, Non-Functioning Thyroid Tumor.

\section{はじめに}

機能性および非機能性甲状腺腫瘍のそれぞれについて生化学的特徵, 特にチログロブリン（以下 $\mathrm{Tg})$ の性状についてわれわれはすでに検討してきだ”。その結果, Tgのヨウ素含量が非機能性腫 瘍では周辺部が平均 $0.49 \%$ でるのに対し, 結節部は平均 $0.11 \%$ と顕著な减少を示した。これに対 し，機能性腫瘍では逆に周辺部（平均 $0.16 \%$ ）が低下し, 結節部（平均 $0.30 \%$ ）はそれよりも高いこ とが両タイプの腫瘍を区別する生化学的な特徵であることを示した。今回，同一患者で両タイプの 腫瘍を有する症例について検討する機会を得た。両タイプが共存する場合，相互の関係がどのよう 
になっているか, それぞれの腫痬は本来の特徵を維持しているのかどうか等について, 従来, 殆ど 報告が見られない。今回, 一例ではあるが, とくに $\mathrm{Tg}$ のヨウ素含量, レクチンとの親和性などに ついて解析をおこない, 個々の場合の特徴と比較検討した。

症例

患者：52才 女性

主訴：前頸部の腫大

現病歴：1987年6月, 乳腺・甲状腺の集団検診にて, 前頸部腫瘤を指摘される。近医受診し, 甲状 腺の aspiration cytology を施行され, 悪性所見を認めず, 腺腫様甲状腺腫の診断にて経過観察と なる。

1987年8月, 動悸が出現するようになり他院受診し, 検査の結果 plummer 病の診断にて当科紹 介となる。

1988年2月，手術目的にて入院となる。

既往歴・家族歴：特記すべきことなし

甲状腺機能に関する初回検査值 :
TSH (5.7以下)
$: 0.01 \mu \mathrm{U} / \mathrm{ml}$
$\mathrm{FT}_{4}(0.81 \sim 2.13)$
$: 2.48 \mathrm{ng} / \mathrm{ml}$
$\mathrm{T}_{3}(0.79 \sim 1.95)$
$: 1.8 \mathrm{ng} / \mathrm{ml}$
$\operatorname{Tg}$ (30以下)
$: 170 \mathrm{ng} / \mathrm{ml}$
$\mathrm{T}_{4}(5.6 \sim 12.0)$
$: 12.5 \mu \mathrm{g} / \mathrm{dl}$
MHA (-), TA (-)

甲状腺シンチグラム所見 : 甲状腺右葉上部に集積が認められた (Fig.1)。

超音波検查所見：境界比較的明瞭で内部エコーはやや不均一な腫瘤が，右葉上部に一個，右葉・左 葉下部に複数個認められた (Fig.2)。

以上の結果から，機能性結節と非機能性結節の合併例と診断し手術を施行した。

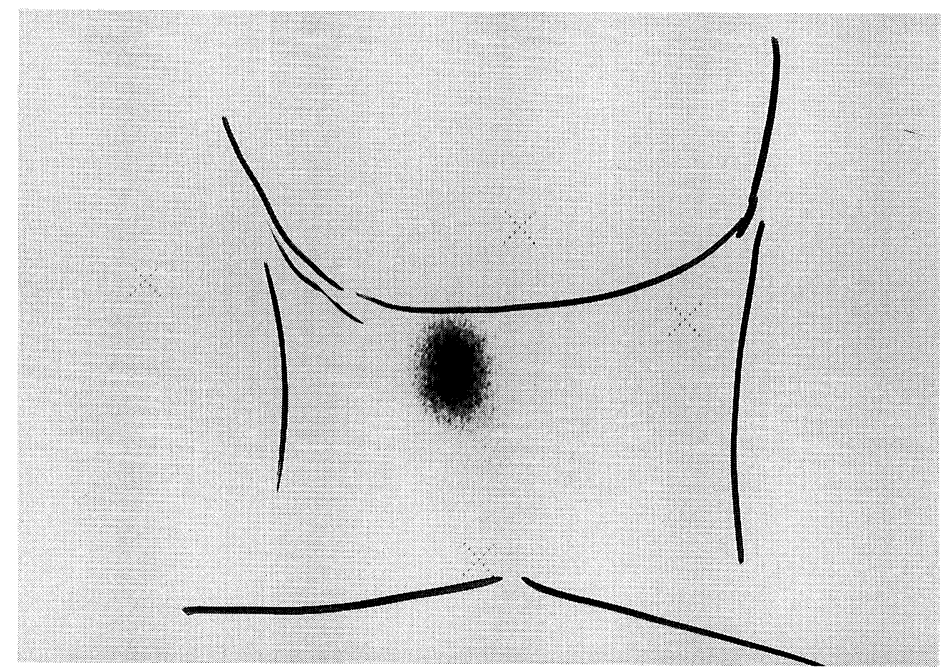

Fig. 1 Preoperative scintigraphy. ( ${ }^{123}$ I Scintigraphy)

Hot nodule is observed in the right lobe. 
手術：甲状腺右葉・峡部・左葉部分切除。

切除標本所見: 腫瘍は右葉・峡部・左葉下部に複数認められ, 淡褐色充実性, 軟性であった（Fig. 3)。

病理所見 : 腺腫様甲状腺腫で, 悪性像は認められなかった。光顕像では, 結節性病変は大小様々な follicle からなり，被膜形成は乏しく，また周辺甲状腺組織への明らかな圧排所見は認められなかっ た (Fig.4)。Fig.5, 6は機能性結節部（右葉上部の腫瘍）と非機能性結節部（左葉下部の腫瘍）の

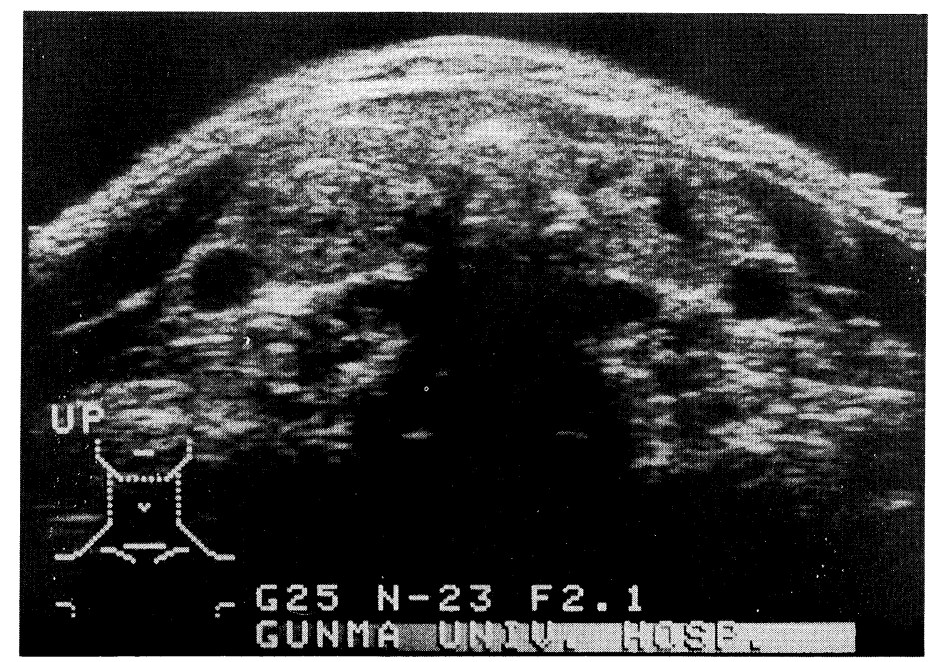

Fig. 2 Sonographic findings, clearly shaped masses of which internal echoes are heterogenous are noted in each lobes.

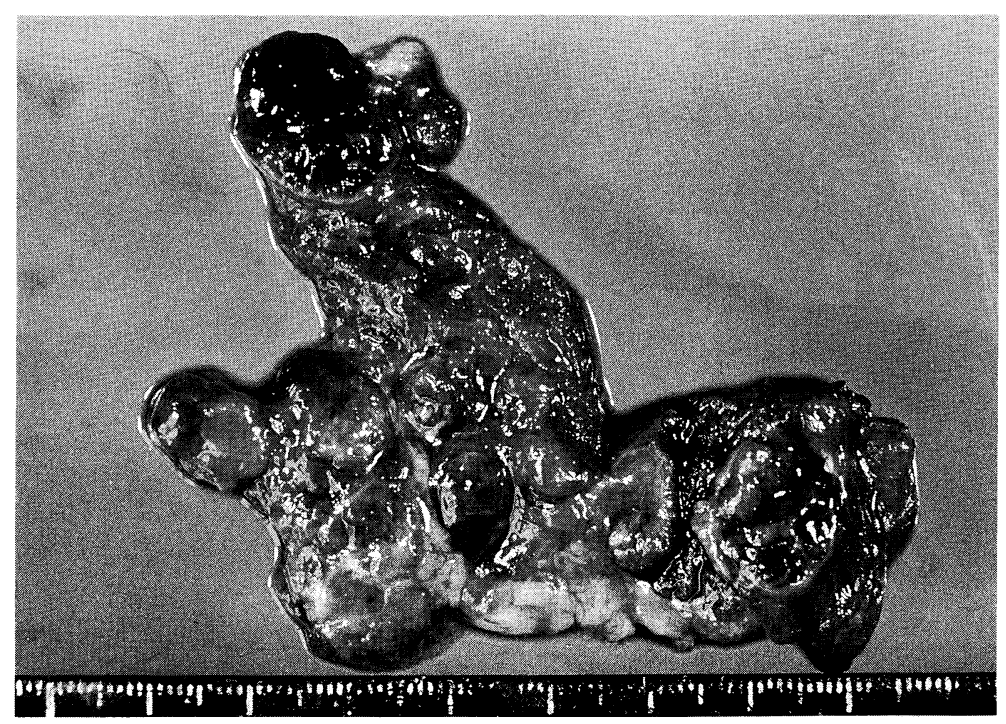

Fig. 3 Resected specimen.

Tumors are recognized in the right and left lobes.

\section{第68巻 第 8 号}


電顕像である。機能性結節部の細胞は丈が高く, 円柱状となり腺腔面にはマイクロビライが発達し て見られる。細胞質内にはライソゾーム顆粒が多く認められ, 粗面小胞体, ミトコンドリアの発達 も良く，機能性を示唆している。また非機能性結節部は偏平ないし立方状の濾胞上皮が一層にコロ イド腔を囲んで配列している。腺腔側のマイクロビライは短く小数散在性に認める。細胞内小器官 の発達も一般に不良であり非機能性を示唆している。

尚，術後この患者の血中 Tg レベルは，正常範囲に戻り $(14 \mathrm{ng} / \mathrm{ml})$ ，経過良好である。

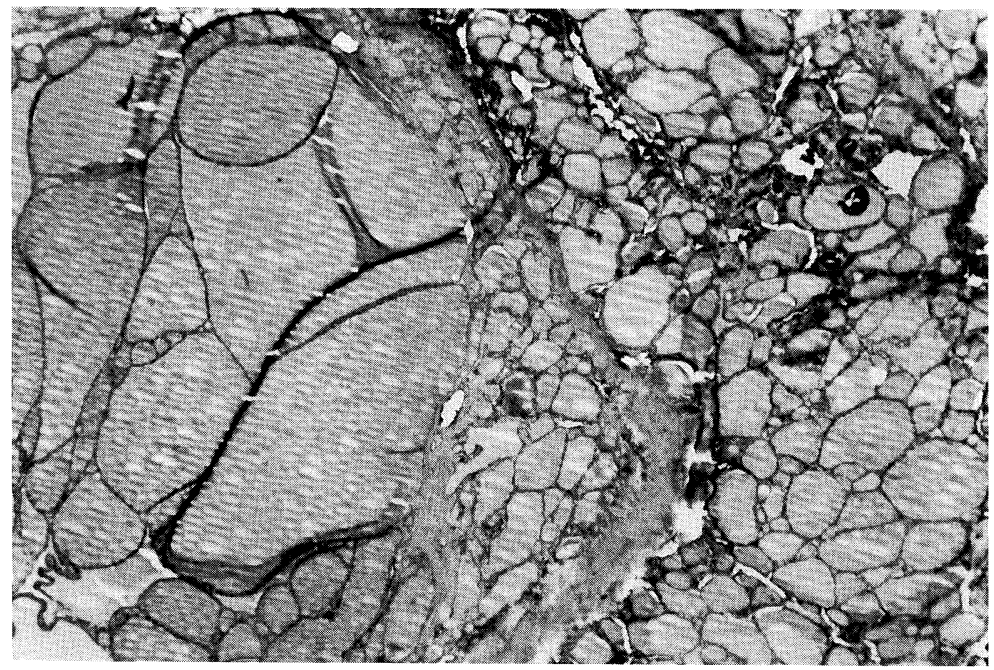

Fig. 4 A nodular region and the adjacent thyroid tissue (H.E.).

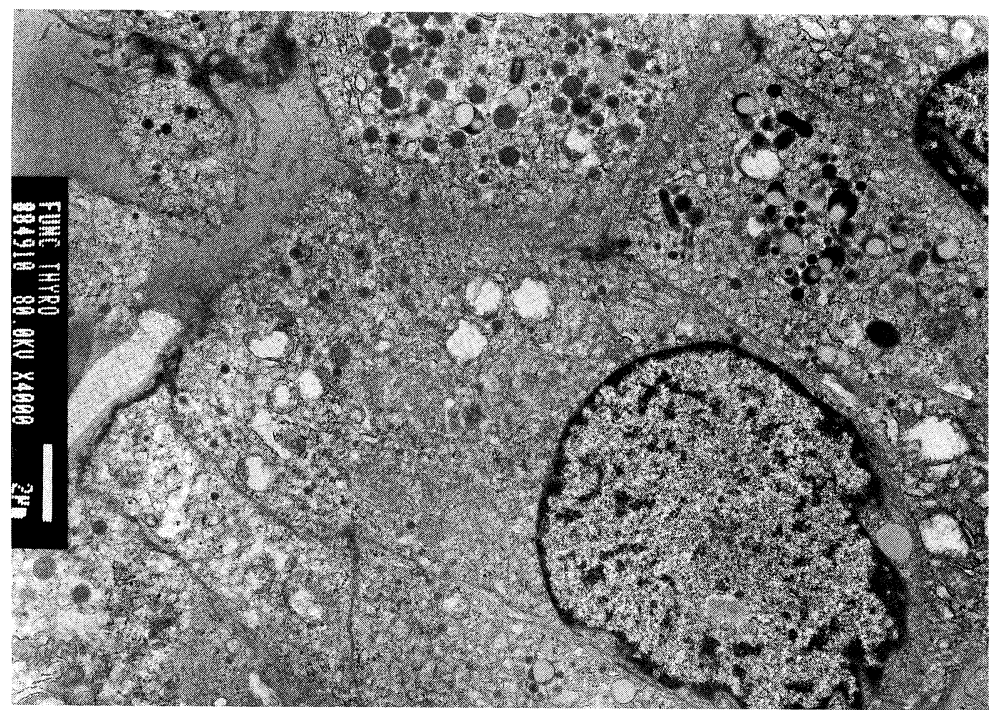

Fig. 5 Electron microscopic findings of the functioning nodule. 


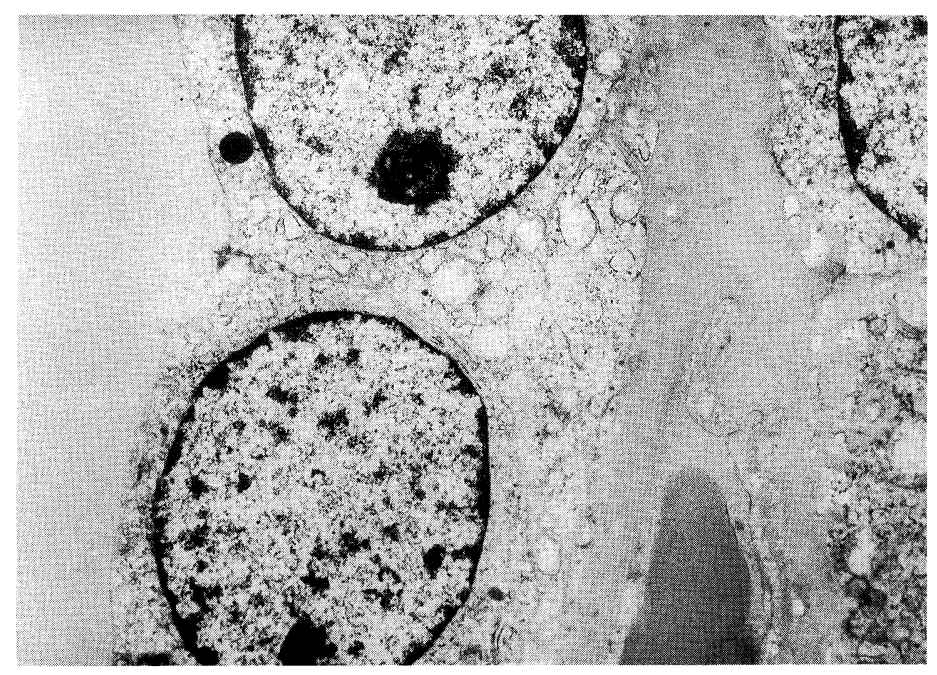

Fig. 6 Electron microscopic findings of the non-functioning nodule.

\section{分 析 方 法}

\section{1. チログロブリンの精製}

甲状腺腫瘍を中心に手術で摘出した組織を腫瘍部とそれに接した部分に分離し, 後で組織学的に 正常と確認したものを周辺部組織とした。甲状腺組織から $\mathrm{Tg}$ の精製は基本的には既に発表ずみの 方法で2)，スライスにしてイオン強度 $0.1, \mathrm{pH} 6.5$ の燐酸緩衝液中で約 2 時間低温に浸し可溶性蛋白 質を抽出した。この抽出液を $6 \%$ アガロース・ゲル $(\mathrm{Bio} \mathrm{Gel} \mathrm{A-5m)} \mathrm{カラム}(2.5 \times 100 \mathrm{~cm})$ で直接 ゲル滤過を括こない $\mathrm{Tg}$ 分画を取り出した ${ }^{344)}$ 。この方法で分離した $\mathrm{Tg}$ はゲル電気泳動的に均一で あった。Tg 濃度は従来から簡便的に用いられている $\mathrm{E}_{280 \mathrm{~nm}}^{1 \%}=10$ として求めた ${ }^{2)}$ 。

\section{2. 化学分析}

Tg のヨウ素含量は Technicon autoanalyzer を用い亜砒酸拉よび硫酸第二セリウムアンモニウ ムによる亜砒酸セリウム反応で測定した ${ }^{5)}$ 。

\section{3. 赤血球疑集阻止試験}

$\operatorname{Tg}$ の糖鎖構造に関する若干の知見を得るためレクチンとの親和性について検討した。すなわち $\mathrm{Tg}$ と各種レクチンを反応させ，レクチンの赤血球凝集能をどの程度 $\mathrm{Tg}$ が阻害するかをみる赤血 球凝集阻止試験を抏こなった。これは一定量のレクチンと倍々希釈をした Tgのシリーズを反応さ せ, 約 2 時間室温で放置した後それぞれに一定量の赤血球を加え, 凝集が起こる点の $\mathrm{Tg}$ の希釈度 をもって, Tgのレクチンに対する親和性とした吕。

今回用いたレクチンは, 桾鎖コア部分でマンノースの枝分かれ構造部分と親和性のある Con A (タチナタ豆凝集素), 複合型糖鎖の $\mathrm{Gal}$ (ガラクトース) $\rightarrow \mathrm{GlcNAc}$ (グルコサミン) 結合部分を認 識する RCA (ヒマ豆凝集素), 複合型糖鎖で GlcNAc $\rightarrow$ Man (マンノース) 構造を強く認識すると いわれている PHA (インゲン豆凝集素)，およびュア部分の GlcNAcとくに混合型糖鎖に強い親和 性のあるWGA (小麦胚芽凝集素) など四種類を用いた。 


\section{結果}

\section{1. 腫瘍部および周辺正常部組織の $\mathrm{Tg}$ 含量}

従来の知見では良性非機能性および良性機能性のいずれも腫瘍部および周辺部とも組織単位重量 当たりの $\mathrm{Tg}$ 含量は, 正常組織 (平均 $68 \mathrm{mg} / \mathrm{g}$ 組織) に比べ，その $60 \%$ から $85 \%$ と若干の低下を示 した ${ }^{1)}$ これに対し本症例では Table 1に示したごとく周辺部 $67 \mathrm{mg} / \mathrm{g}$, 機能性部 $60 \mathrm{mg} / \mathrm{g}$, と Tg 含 量は正常範囲にあった。これに対し, 非機能性部では従来の知見とは逆に, $116 \mathrm{mg} / \mathrm{g}$ と $\mathrm{Tg}$ 含量 がかなり高い值を示した。

\section{Tgのヨウ素含量}

一般に, 良性非機能性結節では腫瘍部 Tg のヨウ素含量は正常組織 $T g$ のそれに比べ $1 / 3$ 程度に 低下し, 甲状腺ホルモンの形成能が隇退する。逆に周辺部は正常組織より高いヨウ素含量を示す。 これに対し, 良性機能性結節では, 腫瘍部のヨウ素含量は正常組織に比べ殆ど低下が認められず, 反対に周辺部 $\mathrm{Tg}$ でヨウ素含量が半隇するのが特徵であった ${ }^{11}$ 。本症例の場合は周辺部が $0.36 \%$ で あるのに対し, 非機能性腫瘍部は $0.14 \%$ と顕著な低下を示した。これに対し機能性腫瘍部では $0.50 \%$ と従来の個々の場合と若干異なり正常組織 $\mathrm{Tg}(0.33 \%)$ よりも1.5倍も高い值を示した。（Table 1)。

\section{3. 赤血球凝集阻止試験}

Tg とレクチンの親和性を示す赤血球凝集反応における Tg の阻害効果の結果を Table 2 に示した。

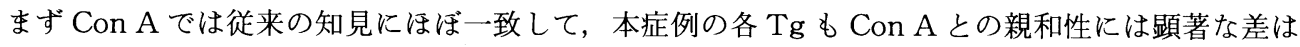
見られない。これに対し RCA やWGA との反応では非機能性腫瘍 Tg が，またPHA には周辺部 分の $\mathrm{Tg}$ に強い親和性が見られ，同一患者でも組織部分の由来によって糖鎖構造の異なることが示 唆される結果であった。

Table $1 \mathrm{Tg}$ content in the tissue and iodine content in the $\mathrm{Tg}$.

\begin{tabular}{|c|c|c|}
\hline Thyroid tissue & $\operatorname{Tg}(\mathrm{mg}) / \mathrm{Tissue}(\mathrm{g})$ & $\mathrm{I} / \mathrm{Tg}(\%)$ \\
\hline \multicolumn{3}{|l|}{ A. } \\
\hline Adjacent periphery & 67 & 0.36 \\
\hline Non-functioning tumor & 116 & 0.14 \\
\hline Functioning tumor & 60 & 0.50 \\
\hline \multicolumn{3}{|l|}{ B. } \\
\hline Normal & $68 \pm 26(4)$ & $0.33 \pm 0.14\left(\begin{array}{ll}1 & 3\end{array}\right)$ \\
\hline \multicolumn{3}{|c|}{ Non-functioning tumor } \\
\hline Tumor & $42 \pm 35(11)$ & $0.11 \pm 0.11\left(\begin{array}{ll}1 & 0\end{array}\right)$ \\
\hline Periphery & $41 \pm 16(9)$ & $0.49 \pm 0.24(14)$ \\
\hline \multicolumn{3}{|l|}{ Functioning tumor } \\
\hline Tumor & $55 \pm 12(9)$ & $0.30 \pm 0.06(9)$ \\
\hline Periphery & $58 \pm 10(7)$ & $0.16 \pm 0.07(7)$ \\
\hline
\end{tabular}

A : Present case(patient) co-existed with two types of tumor.

$B$ : Mean values from the patients with non-functioning or with functioning tumor. Nunbers in parentheses represent numbers of patients. A part of data shown in Table 1B cited from previous report ${ }^{1}$. 
Table 2 Inhibitory action of human $\mathrm{Tg}$ on agglutination of erythrocyte-lectin system.

\begin{tabular}{|c|c|c|c|c|c|}
\hline \multirow{2}{*}{ Inhibitor $(\mathrm{Tg})$} & & \multicolumn{4}{|c|}{ Relative inhibition titer } \\
\hline & & ConA & $\mathrm{RCA}$ & PHA & WGA \\
\hline \multicolumn{6}{|l|}{ A. } \\
\hline Adjacent periphery & & 2 & 1 & 128 & 2 \\
\hline Non-functioning tumor & & 1 & 8 & 64 & 16 \\
\hline Functioning tumor & & 4 & 1 & 8 & 2 \\
\hline \multicolumn{6}{|l|}{ B. } \\
\hline Normal & (K. M) & 16 & 128 & - & 16 \\
\hline Non-functioning tumor & (T. T) & 16 & 32 & - & 128 \\
\hline Functioning tumor & (N. K) & 16 & 64 & - & 16 \\
\hline Carcinoma & (S. H) & 16 & 64 & - & 128 \\
\hline
\end{tabular}

\footnotetext{
A : Patient shown in the present paper.

B ( ): Name of individual patient ${ }^{6)}$.

- : not determined
}

甲状腺腫瘍は圧倒的に非機能性の場合が多く, 機能性結節は比較的例数が少ない。我々は, 両夕 イプをそれぞれ単独に持つ患者についての Tg 抢よび甲状腺ペルオキシダーゼ（TPO）活性など生 化学的性状について既に報告してきだ象。今回は両タイプの結節を持つ同一患者の Tgについて1 例ではあるが機能性と非機能性腫瘍が共存する状況におけるTgのヨウ素含量やレクチンとの親和 性について検討ができた。

その結果, $\mathrm{Tg}$ 含量に関しては正常組織に比べ，周辺部や機能性結節では顕著な変化はみられな かったが, 非機能性結節部分で116mg と高い值を示した。この值は単独の非機能性での結果 $(42 \pm$ $35 \mathrm{mg})$ より, 極めて高いばかりでなく, 健常人での含量 $(68 \pm 26 \mathrm{mg})$ よりも多い"), これは $\mathrm{Tg}$ 含 量が腫瘍の悪性化とともに顕著な减少を示すとい5単独タイプ従来の知見と逆の結果であった。

次にヨウ素含量は非機能性結節部分で $0.14 \%$ と低く, 従来の知見と一致するが, 機能性結節の部 分は $0.50 \%$ で正常組織 Tg に比べ顕著に高くなっているのが単独タイプの結果と異なる。さらに周 辺部に関しては Tg 含量およびョウ素含量のいずれもほぼ正常組織と同じ値を保持している点が, 単独タイプの腫瘍周辺部の場合と異なっている。すなわち $\mathrm{Tg}$ 含量では機能性腫瘍の周辺部の特徵 を, ヨウ素含量では非機能性腫瘍の周辺部の特徵を示している。

非機能性結節部分の $\mathrm{Tg}$ 含量が高い原因については目下のところ明らかにできないが, 機能性単 独のケースではあるが, 今回の結果に似たよらな機序が報告されており, その中で機能性結節の産 生する $\mathrm{T}_{3}, \mathrm{~T}_{4}$ が直接同一甲状腺の多くの部分を抑制する short loop negative feedback 機構が唱兄 られている ${ }^{910) 111}$ 。今回の患者も血中 $T_{3}, T_{4} レ$ レ゙が若干高く, TSH レベルは極めて低いことから 機能性結節および周辺から分泌される甲状腺ホルモンが paracrine 的に非機能性結節に作用して TSH に対する反応性を低下させ, $\mathrm{Tg}$ の酵素的加水分解能が落ち, その結果 $\mathrm{Tg}$ が結節に貯まって しまったのではないかと考学られる。この場合の Tgがヨウ素含量が低いことは, 我々がすでに報 
告している単独の場合に見られるように，非機能性腫瘍部では概して甲状腺ペルオキシダーゼ （TPO）活性は高いが，ヨウ素の取り込み機構あるいは TPO 以外のヨウ素の有機化機構に欠陥が あり，その結果として，Tgのヨウ素含量が低下しているものと考えられる17)。

$\mathrm{Tg}$ の糖鎖に関しては正常組織の $\mathrm{Tg}$ には典型的な高マンノース型糖鎖と複合型糖鎖を多数もっ ていることが知られている ${ }^{12)}$ 。さらに腫瘍 $\mathrm{Tg}$ になると両タイプの比に大きな変化が見られ，甲状 腺癌, 非機能性良性腫瘍, バセドウ病などでは高マンノース型が顕著に低下し, 相対的に複合型が 増加し ${ }^{13)}$ ，腫瘍の悪性化によって異常糖鎖や巨大分子量の糖鎖構造のものが顕著に現れてくること

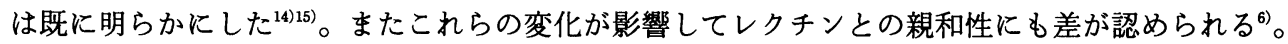

今回の結果, 非機能性 Tg は RCA や WGA と強い親和性があるのは, 高マンノース型糖鎖より も複合型および混合型糖鎖が多く，糖鎖末端を占めるシアル酸の顕著な減少 $(\mathrm{RCA})$, および正常 組織 Tg ではほとんど見られない糖鎖コア部分へのグルコサミンのbi-secting な結合 (WGA)，あ るいは複合型で多岐構造 (polyantennary) や混合型糖鎖（WGA）があるものと思われ，非機能性 腫瘍 $\mathrm{Tg}$ の特徵といわれる従来の知見に一致する6(13)14)。

次に機能性部 $\mathrm{Tg}$ とレクチンの反応を検討した知見は従来見られないが，今回の結果では Con A との親和性が若干高く, PHA とは弱い反応であることから癌（非機能性）や良性腫瘍の Tg と異 なり，複合型糖鎖よりも高マンノース型糖鎖の含量が高いことが示唆される。同様のことは，びま 几性甲状腺腫の $\mathrm{Tg}$ で生じている ${ }^{12)}$ 。また正常組織 $\mathrm{Tg}$ に似て非高マンノース型糖鎖には異常糖鎖 がほとんど含まれていないと考えられる(WGA)。

また周辺部 $\mathrm{Tg}$ は糖鎖のプロセシングが進行し, 高マンノース型から複合型糖鎖がかなり形成さ れているが (PHA)，異常桾鎖はほとんど無いようである (WGA)。この点では正常組織 Tg に類似 すると考えられる。

\section{結 論}

甲状腺で機能性および非機能性結節が共存した症例を経験し，それぞれの腫瘍の組織 Tg につい て, ヨウ素含量，糖鎖構造などを生化学的に検討した。

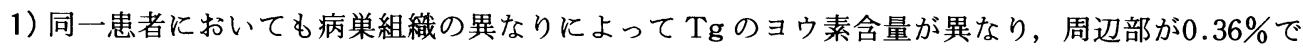
あるのに対し, 非機能性部では $0.14 \%$ と大きく減少しているが, 単独の症例と異なり $\mathrm{Tg}$ 含量では 逆に顕著な増大を示している。一方, 機能性部分のヨウ素含量は $0.50 \%$ と周辺部よりもさらに高く, $\mathrm{Tg}$ 含量もほぼ正常範囲の值を示している。これは，単独の症例では周辺部 Tg のヨウ素含量が低 下するのが特徵であることとは異なる結果であった。従ってこれらの結果から今回の患者の甲状腺 全体としての機能及びョード代謝は，それぞれ機能性あるいは非機能性単独の場合と異なり，機能 性結節部分・非機能性結節部分・周辺部それぞれの相互関与のあることが示唆された。

2) レクチン類との反応性から機能性 Tg と非機能性 Tg はヨウ素含量だけでなく，糖鎖構造にも差 が見られ，とくに非機能性部では従来単独の場合と一致して，腫瘍に特有な異常糖鎖が存在するも のと思われた。機能性部と周辺部 Tg は正常組織 Tg に似た糖鎖組成で，異常糖鎖は含まないが, 機能性部は糖鎖のプロセシングがあまり進んでおらず，高マンノース型が多いと考えられる。

本論文の一部は，第61回日本内分泌学会甲状腺分科会に打いて報告した。 


\section{文献}

1 ）樽谷 修, 阿部展祐輝, 石田常博, 泉雄 勝, 高橋礼子, 斎藤公幸, 河野陽一, 桧山義雄, 吉村弘一, 細谷東一郎：機能性結節性甲状腺腫の生化学的特徵. 日内分泌, 1988；64：390401

2) Ui, N., Tarutani, O.: Purification of hog thyroglobulin. J. Biochem. 1961; 50: 508-518

3) Tarutani, O., Kondo, T., D.J. Smith, S. Shulman: Isolation and properties of thyroglobulin-related $4 \mathrm{~S}$ protein in the soluble fraction of thyroid tissue. J. Biochm. $1978 ; 333-340$

4 ) Tarutani, O., Kondo, T., D.J. Smith, S. Shulman: Subunit structure of $27-$ s thyroid iodoprotein. Endocrinol. Japon. 1978; 23: 305-311

5 ) Gross, W.G., Wood, L.K., McHargue, J.S.: Spectrophotometric determination of iodine. Anal. Chem. 1948; 20: 900-901

6 ) Tarutani, O., Ui, N.: Properties of thyroglobulin from normal thyroid and thyroid tumor on a concanavalin A Sepharose column. J. Biochem. 1985; 98: 851-857

7) Yoshimura, H., Ito, K., Tarutani, O., Hosoya, T.: Peroxidase activity and thyroglobulin iodination activity of thyroid in non-functioning thyroid tumors. Acta Endocrinol. 1988; 118: 147-153

8 ）桧山義雄, 細谷東一郎, 凓谷 修, 伊藤国彦: バセドウ病甲状腺のペルオキシダーゼ活性一 MMI, PTU, 無気ヨード投与による差異. 日内分泌, 1986；62:1-8

9) Takasu, N., Sato, S., Tukui, T., Yamada, T., Furihata, R., Makiuchi, M.: Inhibitory Action of Thyroid Hormone on the Activation of Adenyl Cyclase-Cyclic AMP System by Thyroid Stimulating Hormone in Human Thyroid Tissues from Euthyroid Subjects and Thyrotoxic Patients. J. Clin. End. Metab. 1974; 39: 772-778

10) Shishiba, Y., Takaishi, M., Miyachi, Y., Ozawa, Y.: Alteration of Thyroidal Responsiveness to TSH Under the Influence of Circulating Thyroid Hormone: Short Feed-Back Regulatory Effect. Endocrinol. Japon. 1975; 22: 367-371

11）白水明代, 井上謙次郎, 岡村 建, 江頭芳樹, 尾前照雄, 久次武晴, 自見雅文: 機能性甲状腺 結節 (Autonomous Functioning Thyroid Nodule) 及び周辺組織におけるコード代謝. 日内 分泌, 1978; 54: 866-875

12) Spiro, R.G.: The Carbohydrate Units of Thyroglobulin. J. Biol. Chem. 1965; 240: $1603-1610$

13) Hotta, T., Ishihara, H., Tejima, S., Tarutani, O., Takahashi, N.: Comparative study of the oligosaccharides of human thyroglobulins obtained from normal subjects and patients with various diseases. J. Appl. Biochem. 1985; 7: 98-103

14) Yamamoto, K., Tsuji, T., Tarutani, O., Osawa, T.: Structural changes of carbohydrate chains of human thyroglobulin accompanying malignant transformations of thyroid glands. Eur. J. Biochem. 1984; 143: 133-144 
15) Yamamoto, K., Tsuji, T., Tarutani, O., Osaw, T.: Phosphorylated high mannose-type and hybrid-type oligosaccharide chains of human thyroglobulin isolated from malignant thyroid tissue. Biochem. Biophys. Acta 1985; 838: 84-91

（受付日：'91.10.16）

（採択日：'92. 5.18） 